\title{
Risk Factors for Severe Hyperbilirubinemia in Neonates
}

\author{
MAY-JEN HUANG, KA-EM KUA, HSIU-CHEN TENG, KUNG-SHENG TANG, \\ HUI-WEN WENG, AND CHING-SHAN HUANG
}

\begin{abstract}
Departments of Laboratory Medicine [M.J.H.] and Pediatrics [K.E.K], Cathay General Hospital, Jen-Ai Road, Taipei 106, Taiwan; and Departments of Medical Management [H.C.T] and Medical Technology

[K.S.T., H.W.W., C.S.H.], Fooyin University, Ta-Liao Hsiang, Kaohsiung Hsien 831, Taiwan
\end{abstract}

ABSTRACT

\begin{abstract}
The incidence of severe neonatal hyperbilirubinemia is higher in Asians than in whites. A case-control study was designed to investigate the effects of eight known risk factors [breast feeding, ABO incompatibility, premature birth, infection, cephalohematoma, asphyxia, glucose-6-phosphate dehydrogenase (G6PD) deficiency, and variant UDP-glucuronosyltransferase 1A1 (UGT1A1) gene] and a suspicious analog [organic anion transporter 2 (OATP 2) gene] on severe hyperbilirubinemia in Taiwanese neonates. The 72 study subjects and 100 hospital control subjects consisted of neonates with peak serum bilirubin levels $\geq 342 \mu \mathrm{M}$ and $<256.5 \mu \mathrm{M}$, respectively. The PCR-restriction fragment length polymorphism method was applied to detect the UGT1A1, OATP 2, and G6PD genes. The results of multivariate logistic regressions, adjusted for covariates, revealed odds ratios (ORs) of 4.64 [95\% confidence interval (CI): 2.25-9.57; $p<$ 0.001 ], 3.36 (95\% CI: $1.54-7.35 ; p=0.002$ ), and 3.02 (95\% CI: $1.30-6.99 ; p=0.010$ ) for neonates who were fed with breast milk, and carry the variant UGT1A1 gene at nucleotide 211 and the variant $O A T P 2$ gene at nucleotide 388, respectively. The
\end{abstract}

ORs, adjusted for covariates, for the other six risk factors were not statistically significant. The ORs in neonates who had one, two, and three significant risk factors were 8.46 (95\% CI: 2.75-34.48; $p<0.001$ ), 22.0 (95\% CI: 5.50-88.0; $p<0.001$ ), and 88.0 (95\% CI: $12.50-642.50 ; p<0.001)$, respectively. In conclusion, neonates who carry the 211 and 388 variants in the UGT1A1 and OATP 2 genes, respectively, as well as feed with breast milk are at high risk to develop severe hyperbilirubinemia. (Pediatr Res 56: 682-689, 2004)
Abbreviations
CGH, Cathay General Hospital
CI, confidence interval
G6PD, glucose-6-phosphate dehydrogenase
OATP 2, organic anion transporter 2
OR, odds ratio
RFLP, restriction fragment length polymorphism
UGT1A1, UDP-glucuronosyltransferase 1A1

Bilirubin is mainly produced in its unconjugated form by the turnover of erythrocytes. It may be transported by the organic anion transporter 2 (OATP 2) (1), and it is then conjugated with glucuronic acid through reaction with UDP-glucuronosyltransferase 1A1 (UGT1A1) in the liver before being excreted into the bile (2). The bilirubin level in neonates is much higher than in adults because the life span of the erythrocytes is relatively short and the capacity for bilirubin elimination is lower than in adults (3). The peak serum levels of unconjugated bilirubin in full-term Asian and American-Indian neonates are double those in white and black populations (4). The

Received November 18, 2003; accepted May 27, 2004.

Correspondence: Ching-Shan Huang, Department of Medical Technology, Fooyin University, 151 Chin-Hsueh Rd., Ta-Liao Hsiang, Kaohsiung Hsien 831, Taiwan; e-mail: chsh.huang@msa.hinet.net

This study was supported by a grant from the National Science Council, Taiwan (contract no. NSC 92-3112-B-242-001).

DOI: 10.1203/01.PDR.0000141846.37253.AF incidence of severe hyperbilirubinemia and kernicterus is also higher among newborn Asian infants (3). These findings suggest that genetic factors may be involved in the development of severe neonatal hyperbilirubinemia.

Glucose-6-phosphate dehydrogenase (G6PD) deficiency is the most common genetic defect, affecting $>400$ million individuals worldwide (5). Furthermore, G6PD deficiency was the main risk factor for development of severe hyperbilirubinemia in Taiwanese neonates in the past (6). The situation has improved, however, since neonatal G6PD screening tests and health education were instituted at the Cathay General Hospital (CGH) in Taipei and nationwide in Taiwan in 1981 (7) and 1987 (6), respectively. Recently, another genetic defect, a variation in the promoter area or within the coding region of the UGT1Al gene, was associated with neonatal hyperbilirubinemia in whites and in Japanese and Taiwanese, respectively $(8-12)$. It has been determined that the $\mathrm{A}(\mathrm{TA})_{7} \mathrm{TAA}$ promoter variant or homozygous $\mathrm{G}$ to $\mathrm{A}$ variation at nucleotide 211 in 
the UGTIAl gene is an additive risk factor for neonatal hyperbilirubinemia in G6PD-deficient white (13-15) and Taiwanese neonates (16).

It was demonstrated recently that OATP 2 is responsible for the transportation of organic anions into hepatocytes (1). This mechanism may also be involved in the transportation of unconjugated bilirubin (1). Although variations at nucleotides 388, 463, 521, and 1463 in the OATP 2 gene have been reported $(17,18)$, the relationship between these variants and hyperbilirubinemia has not been investigated.

Along with other authors, we have reported that at least 15 different types of single-point mutation are responsible for G6PD deficiency in Taiwanese $(7,16,19-21)$. We found that most of the G6PD-deficient neonates who had suffered from hyperbilirubinemia carried the mutation at nucleotide 1376 (7). We also showed that the occurrence of the A(TA) $)_{7}$ TAA allele was relatively rare (14.3 versus $40 \%)$ and that the variation rate within the coding region of the UGTIAl gene was much higher (29.3 versus $0.1 \%$ ) in Taiwanese compared with whites (22). Our previous research indicated that the variation at nucleotide 211 of the UGTIAI gene was highly related to neonatal hyperbilirubinemia $(12,16)$. As severe hyperbilirubinemia still occurs in Taiwanese neonates, it is necessary to understand the real cause(s) of this disease. In this study, therefore, all known risk factors for neonatal hyperbilirubinemia were investigated. To the best of our knowledge, this is the first such investigation of these three genes (G6PD, UGTIA1, and OATP 2) and the first using the OATP 2 gene for the case-control study of neonatal hyperbilirubinemia.

\section{METHODS}

Case subjects and control subjects. Severe neonatal hyperbilirubinemia was diagnosed when a newborn infant had a peak bilirubin level $\geq 342 \mu \mathrm{M}(20.0 \mathrm{mg} / \mathrm{dL})$ in serum within $10 \mathrm{~d}$ of birth. From August 2001 through May 2003 at the CGH, 73 neonates (38 boys and 35 girls) received a diagnosis of this disease. Of the 73 neonates, a male neonate who had hepatitis was excluded. The remaining 72 neonates, with unconjugated bilirubin/total bilirubin $\geq 80 \%$, were enrolled. Prolonged hyperbilirubinemia was defined when bilirubin was $\geq 150 \mu \mathrm{M}$ $(8.8 \mathrm{mg} / \mathrm{dL})$ at day 14 . All 72 neonates with hyperbilirubinemia were monitored for their bilirubin values at 1 mo of age. The
100 control subjects (50 boys and 50 girls) were selected from neonates who were born at the $\mathrm{CGH}$ and had peak serum bilirubin levels $<256.5 \mu \mathrm{M}(15.0 \mathrm{mg} / \mathrm{dL})$ within the first $10 \mathrm{~d}$ of life. All parents of case and control neonates gave consent for their infants to participate in this study, which was approved by the research board of the CGH, Taipei, Taiwan.

Investigation of risk factors. A cohort investigation was subsequently conducted using the hospital records for every case of severe neonatal hyperbilirubinemia and each control subject. The known risk factors for neonatal hyperbilirubinemia [breast feeding (exclusive), ABO incompatibility (simply maternal-infant incompatibility in $\mathrm{ABO}$ system), premature birth $(<38 \mathrm{wk})$, infection (by both clinical criteria and culture), cephalohematoma, asphyxia (Apgar score $\leq 6$ ), G6PD deficiency, and carriage of the variant UGTIAl gene] were investigated. Data for the first seven items were obtained from the chart as the records for these were complete and because neonatal screening of G6PD activity has been performed at the CGH since 1981 using umbilical-cord blood samples (7). For determination of UGTIAl gene status, total genomic DNA was isolated from the umbilical-cord blood cells using a blood DNA isolation kit (Maxim Biotech Inc., San Francisco, CA). The PCR-restriction fragment length polymorphism (RFLP) method was applied to detect the known variant sites in the UGT1A1 gene in Taiwanese: promoter area, nucleotides 211, 686, 1091, and $1456(12,16,22)$. The natural or mutagenic primers, restriction enzymes, and digested restriction fragment sizes of the five known variants are listed in Table 1. The PCR mixture $(20 \mu \mathrm{L})$ consisted of $200 \mathrm{ng}$ of DNA, $20 \mathrm{ng}$ of each primer, $1.25 \mathrm{mM}$ of each dNTP $(3.2 \mu \mathrm{L})$, buffer solution (100 $\mathrm{mM}$ of Tris- $\mathrm{HCl}, 500 \mathrm{mM}$ of $\mathrm{KCl}, 15 \mathrm{mM}$ of $\mathrm{MgCl}_{2}$, and $0.01 \%$ gelatin), and $0.4 \mathrm{U}$ of thermostable DNA polymerase (Dynazyme, Finnzymes Inc., Espoo, Finland). The PCR amplification was performed in a DNA thermal cycler (PerkinElmer Cetus, Norwalk, CT) for 35 cycles of denaturation for 1 min at $94^{\circ} \mathrm{C}$, annealing for $1 \mathrm{~min}$ at $55^{\circ} \mathrm{C}$, primer extension for $1 \mathrm{~min}$ at $72^{\circ} \mathrm{C}$, and a final extension for $10 \mathrm{~min}$ at $72^{\circ} \mathrm{C}$. The PCR product was digested with the appropriate restriction enzyme and analyzed on a 3\% agarose gel (NuSieve 3:1, Cambrex Bio Science Inc., Rockland, ME). For confirmation of results performed with the PCR-RFLP method, sequence of UGT1A1 gene in 20 randomly selected DNA samples were

Table 1. Natural or mutagenesis primers, restriction enzymes, and UGT1A1 gene variations*

\begin{tabular}{|c|c|c|c|c|}
\hline $\begin{array}{l}\text { Position } \\
\text { (cDNA) }\end{array}$ & Primers & Sequence & $\begin{array}{c}\text { Restriction } \\
\text { enzyme }\end{array}$ & $\begin{array}{c}\text { Result } \\
\text { (bp) } \dagger\end{array}$ \\
\hline 211 & U1F1 & 5'AGATACTGTTGATCCCAGTG3' & Ava II & G $128+18$ \\
\hline $\mathrm{G} \rightarrow \mathrm{A}$ & U211R & 5'CTTCAAGGTGTAAAATGGTC3' & & A 146 \\
\hline $\mathrm{C} \rightarrow \mathrm{A}$ & U1R2 & 5'CGATCCAAAGTAATACATCTG3' & & A $242+132+51$ \\
\hline 1091 & $\mathrm{U} 4 \mathrm{~F} 2$ & 5'GCCAACATATCCTACATTGC3' & $\mathrm{Bcl} \mathrm{I}$ & C 209 \\
\hline $\mathrm{C} \rightarrow \mathrm{T}$ & U1091R & 5'GTGATAAAGGCACGGGTGAT3' & & T $190+19$ \\
\hline Promoter & $(\mathrm{TA}) \mathrm{F}$ & 5'TAACTTGGTGTATCGATTGGT3' & & $\mathrm{A}(\mathrm{TA})_{6} \mathrm{TAA} 77$ \\
\hline $\mathrm{A}(\mathrm{TA})_{\mathrm{n}} \mathrm{TAA}$ & $(\mathrm{TA}) \mathrm{R}$ & 5'CTTTGCTCCTGCCAGAGGTT3' & & $\mathrm{A}(\mathrm{TA})_{7} \mathrm{TAA} 79$ \\
\hline
\end{tabular}

* Underscoring indicates mutagenesis site.

$\dagger$ Size of PCR product. 
determined for exons 1 to 4 , coding region of exon 5 , their flanking intronic regions, and the promoter area with the technique described previously (22). The four known variants (nucleotides 388, 463, 521, and 1463) of the OATP 2 gene were detected using the PCR-RFLP method as described above except for the primers, restriction enzymes, and digested restriction-fragment sizes listed in Table 2. The same PCR-RFLP technique was used for identification of the G6PD mutation for the G6PD-deficient neonates using the 15 natural or mutagenic primers described previously (16). Figure 1 presents PCRRFLP example results for the $G 6 P D$ gene mutation and variants of the UGTIAI and the OATP 2 genes.

Statistical analysis. We analyzed the collected data using the statistical software package (Release 7.0) of Stata (Stata Co., College Station, TX). Odds ratios (ORs) and 95\% confidence intervals (CIs) were estimated for severe hyperbilirubinemia of various risk factors by using univariate and multivariate logistic regression models. $P<0.05$ or a $95 \%$ CI for $\mathrm{OR} \geq 1.0$ was defined as statistically significant.

\section{RESULTS}

Cohort investigation from chart records. Table 3 presents the distributions for risk factors for neonatal hyperbilirubinemia. Of the seven risk factors obtained from chart records, the most prevalent was breast feeding, followed by $\mathrm{ABO}$ incompatibility, premature birth, infection, cephalohematoma, asphyxia, and G6PD deficiency, in descending order. Only three boys in the hyperbilirubinemic group and one boy of the control group were G6PD deficient.

Determination of genes. The predominate variant in the UGT1A1 gene was the G to A substitution at nucleotide 211 (heterozygous and homozygous), followed by the heterozygous variation in the promoter area [A(TA) ${ }_{6}$ TAA/ $\left.\mathrm{A}(\mathrm{TA})_{7} \mathrm{TAA}, 6 / 7\right]$, compound heterozygous variations (e.g. the heterozygous $\mathrm{C}$ to A substitution at nucleotide 686 plus 6/7), and the heterozygous $\mathrm{C}$ to $\mathrm{T}$ substitution at nucleotide 1091 . No carriage of the $\mathrm{T}$ to $\mathrm{G}$ substitution at nucleotide 1456 was detected (Table 3). The status of UGTIAl gene in the 20 randomly selected DNA samples were 10 for the heterozygous variation and two for the homozygous variation at nucleotide 211 , six for the wild type, and two for the compound heterozygous variations (nucleotide 686 plus 6/7). All results were matched with those determined by the sequencing method. The most common variant of the OATP 2 gene was the $\mathrm{G}$ to $\mathrm{A}$ substitution at nucleotide 388 (heterozygous and homozygous), followed by the $\mathrm{T}$ to $\mathrm{C}$ substitution at nucleotide 521 (heterozygous and homozygous) and compound heterozygous variations of these two nucleotides. No carriage of the $\mathrm{C}$ to $\mathrm{A}$ substitution at nucleotide 463 or the $\mathrm{G}$ to $\mathrm{C}$ substitution at nucleotide 1463 was detected (Table 3). Two of the three G6PD-deficient neonates in the hyperbilirubinemic group and the G6PD-deficient subjects in the control group carried the G to $\mathrm{T}$ substitution at nucleotide 1376 , whereas the remaining G6PD-deficient subjects in the hyperbilirubinemic group bore the $\mathrm{G}$ to A substitution at nucleotide 1388 (data not shown).

OR for development of severe hyperbilirubinemia. For detailed analysis, the subjects with $\mathrm{ABO}$ incompatibility were divided by blood type into type A neonates who were born to type $\mathrm{O}$ mothers and type $\mathrm{B}$ neonates who were born to type $\mathrm{O}$ mothers. The subjects who carried the variant UGTIAl gene were divided into nucleotides 211 and 1091, compound heterozygous variations, and 6/7; and the subjects who carried the variant $O A T P 2$ gene were divided into nucleotides 388 and 521 and compound heterozygous variations. The results (OR and $95 \% \mathrm{CI}$ ) of the analysis for the relationship between development of severe hyperbilirubinemia and suspected factors are presented in Table 3. The statistically significant risk factors identified with the univariate logistic regression models were the breast feeding, the variant UGTIAl gene at nucleotide 211, and the variant OATP 2 gene at nucleotide $388(p<$ $0.001, p<0.001$, and $p=0.043$, respectively). Statistical significance was not demonstrated, however, for the ORs for the other subgroups. The results of the multivariate logistic regression models adjusted for the three significant factors are presented in Table 4 and confirm the statistical significance of these factors $(p<0.001, p=0.002$, and $p=0.010$, respectively). When the OR in the neonates who were fed with formula milk and carried wild types in the UGTIAl gene and the OATP 2 gene was defined as 1.00, the ORs were 2.6 and 10.4 times higher in neonates who carried two and three risk factors than in those who carried one risk factor, as that presented in Table 5.

Neonates with prolonged hyperbilirubinemia. All 72 neonates with hyperbilirubinemia received phototherapy with the serum bilirubin level except for two subjects, who rapidly declined below $342 \mu \mathrm{M}$. Blood exchange treatment was given to these two neonates $(500 \mathrm{~mL}$ of packed red blood cells plus $500 \mathrm{~mL}$ of fresh frozen plasma and $1000 \mathrm{~mL}$ of packed red

Table 2. Natural or mutagenesis primers, restriction enzymes, and OATP2 gene variations*

\begin{tabular}{|c|c|c|c|c|}
\hline $\begin{array}{l}\text { Position } \\
\text { (cDNA) }\end{array}$ & Primers & Sequence & $\begin{array}{l}\text { Restriction } \\
\text { enzyme }\end{array}$ & $\begin{array}{c}\text { Result } \\
\text { (bp) } \dagger\end{array}$ \\
\hline 388 & $388 \mathrm{~F}$ & 5'ATAATGGTGCAAATAAAGGGG3' & Taq I & G $128+63+23$ \\
\hline $\mathrm{G} \rightarrow \mathrm{A}$ & $388 \mathrm{R}$ & 5'ACTATCTCAGGTGATGCTCTA3' & & A $151+63$ \\
\hline $\mathrm{C} \rightarrow \mathrm{A}$ & $463 \mathrm{R}$ & 5'ACCTTTTCCСАCTATCTCCGG3' & & A 224 \\
\hline 521 & $521 \mathrm{~F}$ & 5'TTGTCAAAGTTTGCAAAGTG3' & Hha I & Т 209 \\
\hline $\mathrm{T} \rightarrow \mathrm{C}$ & $521 \mathrm{R}$ & 5'GAAGCATATTACCCATGAGC3' & & C $189+20$ \\
\hline
\end{tabular}

* Underscoring indicates mutagenesis site.

$\dagger$ Size of PCR product. 


\section{TT GT TT TT GG}
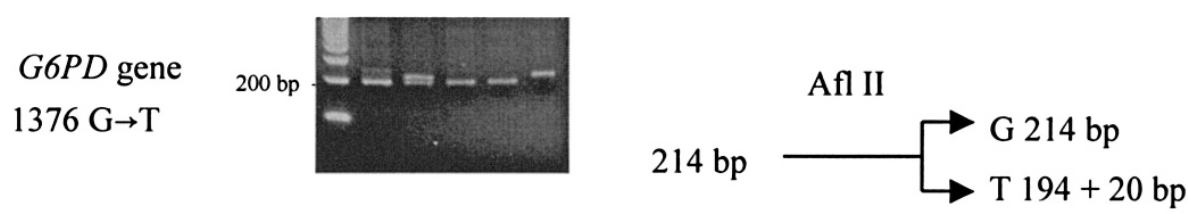

M GA GG GG GG GA

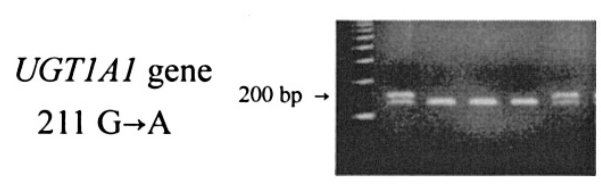

$146 \mathrm{bp}$

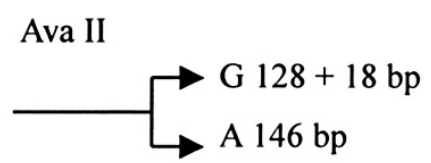

M GG GG AG AG GG

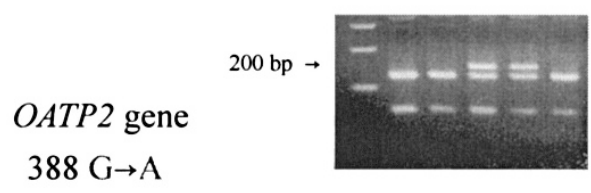

$214 \mathrm{bp} \longrightarrow\left[\begin{array}{l}\text { Taq I } 128+63+23 \mathrm{bp} \\ \mathrm{A} 151+63 \mathrm{bp}\end{array}\right.$

M CT TT TT CT TT
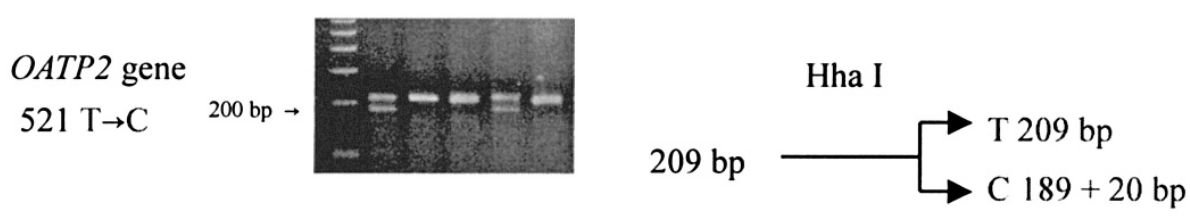

Figure 1. Example results using the PCR-RFLP method to determine G6PD gene mutation type and variants of the UGT1A1 and the OATP 2 genes (M, DNA marker). The $20 \mathrm{bp}$ in the $1376 \mathrm{~T}-G 6 P D$ gene, $18 \mathrm{bp}$ in the $211 \mathrm{G}-U G T 1 A 1$ gene, $23 \mathrm{bp}$ in the $388 \mathrm{G}-O A T P 2$ gene, and $20 \mathrm{bp}$ in the $521 \mathrm{C}-O A T P 2$ gene are too small to be seen.

blood cells plus $250 \mathrm{~mL}$ of fresh-frozen plasma) to correct their serum bilirubin levels. However, 21 of the neonates, including one of the two who received blood exchange, subsequently experienced prolonged hyperbilirubinemia. The risk factor status for these neonates is presented in Table 6 . Thirteen of the 21 newborns carried the variation at nucleotide 211 of the UGT1A1 gene (nine heterozygous and four homozygous). Of these 13 subjects, nine were breast fed and five carried the variant $O A T P 2$ gene at nucleotide 388 (two were breast fed and the other three were not). All serum bilirubin values in the 72 neonates were normal $[<25.65 \mu \mathrm{M}(1.5 \mathrm{mg} / \mathrm{dL})]$ at $1 \mathrm{mo}$ of age.

\section{DISCUSSION}

Neonatal hyperbilirubinemia is common in Asian populations, including Taiwanese. For example, our recent studies indicate that the incidence of neonatal hyperbilirubinemia was $7.8 \%$ (18 of 232) and 15.6\% (33 of 212) in G6PD-normal and G6PD-deficienct Taiwanese neonates, respectively (16), with
$14.6 \%$ (18 of 123) of the neonates with hyperbilirubinemia in one study having peak bilirubin levels $\geq 342 \mu \mathrm{M}$ (12). These findings have enabled consecutive investigation of the cause of neonatal hyperbilirubinemia. Our previous research has focused on the contribution of G6PD deficiency and carriage of the variant UGT1Al gene to the development of neonatal hyperbilirubinemia, to the exclusion of other possible risk factors $(12,16)$. As the relative importance of these factors was not considered in the earlier studies, all eight of the known risk factors as well as an additional suspicious analog were investigated in the present study. No gender difference was demonstrated for any of the nine risk factors except for G6PD deficiency (X linkage), however. Moreover, subjects with G6PD-deficiency were rare (three boys in the affected group and one control). As the male/female ratio was $\sim 1: 1$ for both the case and control groups, the data obtained from the male and female neonates was pooled for analysis. Of the nine investigated factors, breast feeding was the most frequent, confirming the findings of our previous research into neonatal 
Table 3. ORs and $95 \%$ CIs for severe neonatal hyperbilirubinemia associated with suspected factors

\begin{tabular}{|c|c|c|c|c|}
\hline \multirow[b]{2}{*}{ Factor/category } & \multicolumn{2}{|c|}{$n$} & \multirow[b]{2}{*}{ OR $(95 \% \mathrm{CI})$} & \multirow[b]{2}{*}{$p$} \\
\hline & $\begin{array}{c}\text { Case } \\
(N=72)\end{array}$ & $\begin{array}{c}\text { Control } \\
(N=100)\end{array}$ & & \\
\hline \multicolumn{5}{|l|}{ Breast feeding } \\
\hline No & 25 & 71 & 1.00 & \\
\hline Yes & 47 & 29 & $4.60(2.40-8.81)$ & $<0.001$ \\
\hline \multicolumn{5}{|l|}{ ABO incompatibility } \\
\hline None & 54 & 84 & 1.00 & \\
\hline Blood type A neonates & 8 & 8 & $1.56(0.55-4.39)$ & 0.404 \\
\hline Blood type B neonates & 10 & 8 & $1.94(0.72-5.24)$ & 0.188 \\
\hline \multicolumn{5}{|l|}{ Premature birth } \\
\hline No & 60 & 86 & 1.00 & \\
\hline Yes & 12 & 14 & $1.23(0.53-2.84)$ & 0.630 \\
\hline \multicolumn{5}{|l|}{ Cephalohematoma } \\
\hline No & 67 & 99 & 1.00 & \\
\hline Yes & 5 & 1 & $7.39(0.84-64.66)$ & 0.071 \\
\hline \multicolumn{5}{|l|}{ Sepsis Infection } \\
\hline No & 68 & 94 & 1.00 & \\
\hline Yes & 4 & 6 & $0.92(0.25-3.39)$ & 0.902 \\
\hline \multicolumn{5}{|l|}{ Asphyxia } \\
\hline No & 71 & 96 & 1.00 & \\
\hline Yes & 1 & 4 & $0.34(0.04-3.09)$ & 0.337 \\
\hline \multicolumn{5}{|l|}{ G6PD deficiency } \\
\hline No & 69 & 99 & 1.00 & \\
\hline Yes & 3 & 1 & $4.30(0.44-42.25)$ & 0.210 \\
\hline \multicolumn{5}{|l|}{ Variant UGTIAI gene } \\
\hline Wild type & 28 & 55 & 1.00 & \\
\hline Nucleotide 211 & $37 *$ & $20 \dagger$ & $3.63(1.79-7.39)$ & $<0.001$ \\
\hline Nucleotide 1091 & 1 & 1 & $1.96(0.12-32.59)$ & 0.638 \\
\hline Compound variations & 3 & 11 & $0.54(0.14-2.08)$ & 0.367 \\
\hline $6 / 7$ & 3 & 13 & $0.45(0.12-1.72)$ & 0.245 \\
\hline \multicolumn{5}{|l|}{ Variant $O A T P 2$ gene } \\
\hline Wild type & 31 & 53 & 1.00 & \\
\hline Nucleotide 388 & $27 \$$ & $22 \S$ & $2.10(1.02-4.30)$ & 0.043 \\
\hline Nucleotide 521 & $11 \|$ & $20 \pi$ & $0.94(0.40-2.22)$ & 0.888 \\
\hline Compound variations & 3 & 5 & $1.03(0.23-4.59)$ & 0.973 \\
\hline
\end{tabular}

* Seven neonates for homozygous 211 and 30 for heterozygous 211 variations.

$\dagger$ Two neonates for homozygous 211 and 18 for heterozygous 211 variations.

$\ddagger$ Seven neonates for homozygous 388 and 20 for heterozygous 388 variations.

$\S$ Six neonates for homozygous 388 and 16 for heterozygous 388 variations.

$\|$ Two neonates for homozygous 521 and nine for heterozygous 521 variations.

II One neonate for homozygous 521 and 19 for heterozygous 521 variations.

Table 4. Adjusted ORs and 95\% CIs for severe neonatal hyperbilirubinemia associated with independent factors

\begin{tabular}{|c|c|c|c|c|}
\hline \multirow[b]{2}{*}{ Factor/category } & \multicolumn{2}{|c|}{$n$} & \multirow[b]{2}{*}{ Adjusted OR* $(95 \% \mathrm{CI})$} & \multirow[b]{2}{*}{$p$} \\
\hline & $\begin{array}{c}\text { Case } \\
(N=72)\end{array}$ & $\begin{array}{c}\text { Control } \\
(N=100)\end{array}$ & & \\
\hline \multicolumn{5}{|l|}{ Breast milk feeding } \\
\hline No & 25 & 71 & 1.00 & \\
\hline Yes & 47 & 29 & $4.64(2.25-9.57)$ & $<0.001 \dagger$ \\
\hline \multicolumn{5}{|l|}{ Variant UGTIAI gene } \\
\hline Wild type & 28 & 55 & 1.00 & \\
\hline Nucleotide 211 & 37 & 20 & $3.36(1.54-7.35)$ & $0.002 \dagger$ \\
\hline Nucleotide 1091 & 1 & 1 & $2.39(0.11-52.18)$ & 0.580 \\
\hline Compound variations & 3 & 11 & $0.80(0.19-3.36)$ & 0.764 \\
\hline $6 / 7$ & 3 & 13 & $0.32(0.07-1.39)$ & 0.129 \\
\hline \multicolumn{5}{|l|}{ Variant $O A T P 2$ gene } \\
\hline Wild type & 31 & 53 & 1.00 & \\
\hline Nucleotide 388 & 27 & 22 & $3.02(1.30-6.99)$ & $0.010 \dagger$ \\
\hline Nucleotide 521 & 11 & 20 & $1.15(0.42-3.10)$ & 0.789 \\
\hline Compound variations & 3 & 5 & $1.20(0.22-6.54)$ & 0.832 \\
\hline
\end{tabular}

* ORs were derived using the multivariate logistic regression models adjusted for covariates.

$\dagger$ Statistically significant. 
Table 5. Relationship between the number of risk factors and the OR of severe hyperbilirubinemia

\begin{tabular}{|c|c|c|c|c|}
\hline $\begin{array}{l}\text { No. of risk } \\
\text { factors* }\end{array}$ & \multicolumn{2}{|c|}{$n$} & OR $(95 \% \mathrm{CI})$ & $p$ \\
\hline 1 & 20 & 26 & $8.46 \quad(2.75-34.48)$ & $<0.001$ \\
\hline 2 & 22 & 11 & $22.00 \quad(5.50-88.00)$ & $<0.001$ \\
\hline 3 & 8 & 1 & $88.00(12.50-642.50)$ & $<0.001$ \\
\hline
\end{tabular}

* Breast feeding, variant 211 in the UGT1Al gene, and variant 388 in the OATP 2 gene.

$\dagger$ Formula feeding and wild types in the UGTIA1 gene and the OATP 2 gene.

Table 6. Risk factor status for the 21 neonates with prolonged hyperbilirubinemia

\begin{tabular}{lrcc}
\hline Variant $U G T 1 A 1$ gene & $n$ & $\begin{array}{c}\text { Breast } \\
\text { feeding }\end{array}$ & $\begin{array}{c}\text { Variant } \text { OATP 2 } \\
\text { gene at } \\
\text { nucleotide } 388\end{array}$ \\
\hline Wild type & 5 & 3 & $2^{*}$ \\
Nucleotide 211 & 13 & 9 & $5 \dagger$ \\
Nucleotide 1091 & 1 & 1 & 1 \\
Compound variations & 2 & 0 & 0 \\
\hline
\end{tabular}

* One was breast fed.

$\dagger$ Two were breast fed.

hyperbilirubinemia (12). It is known that, in breast milk, there are higher circulating levels of lipoprotein lipase activity, characterized by increased $\beta$-glucuronidase activity and containing $3 \alpha, 20 \beta$-pregnanediol (23). Furthermore, the increased release of fatty acids from triglycerides, catalyzed by the lipoprotein lipase, may interfere with the hepatic uptake and conjugation of bilirubin (23). The $3 \alpha, 20 \beta$-pregnanediol may also inhibit bilirubin conjugation, whereas the $\beta$-glucuronidase induces increased bilirubin resorption from the intestine. Thus, severe neonatal hyperbilirubinemia caused by breast feeding may be explained, in part, at least, by these mechanisms.

In this study, the second frequent risk factor was variation in the UGTIAl gene. There are 1599 nucleotides in the UGTIAI gene, which is located at chromosome $2 \mathrm{q} 37$ (2). The frequency of the $\mathrm{A}(\mathrm{TA})_{7} \mathrm{TAA}$ allele in the promoter area of the UGTIAI gene is lower for Taiwanese (14.3\%) (22), Chinese (16.2\%) (24), Malaysians (18.8\%) (24), and Japanese (10.0-16.8\%) $(10,25,26)$ in comparison with whites $(35.7-41.5 \%)(27-30)$ and Indians (35.1\%) (24). By contrast, the predominant variation of this gene is a $\mathrm{G}$ to $\mathrm{A}$ substitution at nucleotide 211 in Japanese $(10,11,31)$ and Taiwanese $(12,16,22)$; however, this expression has not been observed in whites (27). Although homozygous $\mathrm{A}(\mathrm{TA})_{7} \mathrm{TAA}$ and variant $U G T 1 A 1$ gene at nucleotide 211 are reportedly associated with prolonged neonatal hyperbilirubinemia in breast-fed white and Japanese neonates, respectively $(9,32)$, and homozygous $\mathrm{A}(\mathrm{TA})_{7} \mathrm{TAA}$ is a determining factor for neonatal hyperbilirubinemia $\mathrm{ABO}$ incompatibility (33), the relative predominance of multiple genetic (more than three) and nongenetic factors in neonatal hyperbilirubinemia has not been investigated. This study is the pioneer concerning that situation.

The serum bilirubin values in all of the neonates with hyperbilirubinemia were normal subsequently, indicating that no neonate experienced Criger-Najjar syndrome. Therefore, the determination of unexpected variants in the UGTIAl gene is unnecessary. Moreover, the results of the UGT1Al gene in the randomly selected DNA samples were identical between the PCR-RFLP and the sequencing methods. These data indicate that the results of the UGTIAI gene, determined by the PCR-RFLP method, are reliable. The results of our study reveal that the prevalence $(20 \% ; 20$ of 100$)$ of variant UGT1AI gene at nucleotide 211 in the control group is similar to that (21.4\%; 62 of 290) in healthy Taiwanese adults (22). However, the OR for severe hyperbilirubinemia of this variation in the case group of the present study was statistically significant, indicating that neonates who carry variant 211 in the UGT1Al gene are at high risk for experiencing severe hyperbilirubinemia. The UGT1A1 enzyme activities of the $211 \mathrm{G}$ to A variation in the heterozygous and homozygous state were decreased to 60.2 and $32.2 \%$ of normal in an in vitro expression study (34). These decreased enzyme activities are thought to cause delayed elimination of bilirubin (2) and ultimately occurrence of hyperbilirubinemia. Moreover, most subjects $(61.9 \% ; 13$ of 21$)$ who experienced prolonged hyperbilirubinemia in our study carried the 211 variant, including the four of the seven homozygous variants. The high percentage (57.1\%; four of seven) of prolonged hyperbilirubinemia in neonates who carry the homozygous 211 variant confirms the results of our previous study (12). The risk factors for the two neonates who received blood exchange treatment were carriage of the heterozygous 211 variant in the UGTIAl gene plus breast feeding and carriage of the homozygous 211 variant in the UGTIAl gene and the homozygous 388 variant in the OATP 2 gene. Analysis of these data shows that the variation at nucleotide 211 is probably the most important variant of the UGT1Al gene in Taiwanese.

The other novel finding of our research is that neonates who bear the variant 388 in the OATP 2 gene are also at high risk to develop severe hyperbilirubinemia. The locus of the OATP 2 gene is at chromosome 12p12 (35). As there are 2073 nucleotides and 14 exons in this gene (35), determination of the full sequence of the OATP 2 gene would be tedious. The results of the OATP 2 gene in this report are preliminary, however, because only variations at nucleotides $388,463,521$, and 1463 , determined for white and Japanese populations $(17,18)$, were measured. We found that Taiwanese carry the variations only at nucleotides 388 and 521. Variation at nucleotide 521 (T to C) reduces the transportation function for estrone-3-sulfate to $<50 \%$ of normal in an experiment using HeLa cells (17). In our study, however, the OR for severe hyperbilirubinemia in neonates who carry this variation was not significant. The results may indicate that the 174th amino acid (valine, encoded 
by nucleotides 520-522) of OATP 2 is the binding site for estrone-3-sulfate but not for bilirubin. In this study, the prevalence of variant 388 in the OATP 2 gene in the case and control groups was 37.5 and $22 \%$, respectively, the former higher than the latter, and the OR for severe hyperbilirubinemia of this variation in the case group was statistically significant. Although it has been reported that OATP 2 is involved in the transportation of both conjugated and unconjugated bilirubins (1), the results of a more recent study showed that a role for OATP 2 in hepatocyte bilirubin transport is unlikely (36). However, the results of this study show that the change of amino acid (aspartic acid to asparagine, encoded by nucleotides $388-390$ ) at codon 130 of OATP 2 may reduce the function in unconjugated bilirubin elimination, and the mechanism is worthy of further investigation.

In contrast to the significant risk factors of severe hyperbilirubinemia described above, statistical significance was not demonstrated for the relationships between risk factors such as $\mathrm{ABO}$ incompatibility (type A neonates who were born to type $\mathrm{O}$ mothers and type $\mathrm{B}$ neonates who were born to type $\mathrm{O}$ mothers), premature birth, infection, cephalohematoma, asphyxia, and G6PD deficiency and development of severe neonatal hyperbilirubinemia. As the subjects with these risk factors among both the case and control groups were few, the results seem not to exclude absolutely their relationships with severe hyperbilirubinemia. However, it is reasonable to conclude that these risk factors are less important in the development of severe hyperbilirubinemia in neonates. Although the incidence of hyperbilirubinemia in G6PD-deficient male Taiwanese neonates was double that for control subjects with normal G6PD activity (16), the results of this study demonstrated that the incidence of G6PD deficiency in the case group was low (4.2\%; three of 72) and that the OR for severe hyperbilirubinemia caused by G6PD deficiency is not significantly different from that of the control group. At the $\mathrm{CGH}$, we are aware of any G6PD deficiency within $3 \mathrm{~d}$ of birth, the administration of any oxidative chemical or drugs is avoided, and health education is provided to parents before the infant's discharge from the hospital $(7,16)$. On the basis of this experience, we conclude that severe hyperbilirubinemia caused by G6PD deficiency, without associated polymorphisms in the UGTIA1 or the OATP2 gene, is preventable.

In conclusion, neonates who carry the 211 and 388 variants in the UGTIAI and OATP 2 genes, respectively, as well as feed with breast milk are at high risk to develop severe hyperbilirubinemia. Our results also indicate that the OR is correlated directly with the cumulative number of these three risk factors as present in individual infants. Because our results show that the serum bilirubin concentration in most neonates with hyperbilirubinemia is typically reduced after phototherapy, it seems reasonable to suggest that breast feeding should not be discouraged solely on the basis of temporary severe hyperbilirubinemia that is responsive to phototherapy. Determination of the status of the UGTIAl and OATP 2 genes is strongly recommended in any investigation of unconjugated hyperbilirubinemia in neonates, in both epidemiologic and consultative contexts.

\section{REFERENCES}

1. Cui Y, Konig J, Leier I, Buchholz U, Keppler D 2001 Hepatic uptake of bilirubin and its conjugates by the human organic anion transporter SLC21A6. J Biol Chem 276:9626-9630

2. Clarke DJ, Moghrabi N, Monaghan G, Cassidy A, Boxer M, Hume R, Burchell B 1997 Genetic defects of the UDP-glucuronosyltransferase 1 (UGT1) gene that cause familial non-hemolytic unconjugated hyperbilirubinaemias. Clin Chim Acta 266:63-74

3. Ives NK 1999 Gastroenterology part 1. Neonatal jaundice. In: Rennie JM, Roberton NRC (eds) Textbook of Neonatology, 3rd Ed. Churchill- Livingston, Edinburgh, pp 715-732

4. Halamek LP, Stevenson D 1997 Diseases of the fetus and infants. In: Fanaroff AA, Martin RJ (eds) Neonatal-Perinatal Medicine. Mosby, St. Louis, pp 1345-1389

5. Beutler E 1994 G6PD deficiency. Blood 84:3616-3636

6. Yu MW, Hsiao KJ, Wuu KD, Chen CJ 1992 Association between glucose-6phosphate dehydrogenase deficiency and neonatal jaundice: interaction with multiple risk factors. Int J Epidemiol 21:947-952

7. Huang CS, Hung KL, Huang MJ, Li YC, Liu TH, Tang TK 1996 Neonatal jaundice and molecular mutations in glucose-6-phosphate dehydrogenase deficient newborn infants. Am J Hematol 51:19-25

8. Bancroft JD, Kreamer B, Gourley GR 1998 Gilbert's syndrome accelerates development of neonatal jaundice. J Pediatr 132:656-660

9. Monaghan G, McLellan A, McGeehan A, Li Volti S, Mollica F, Salemi I, Din Z, Cassidy A, Hume R, Burchell B 1999 Gilbert's syndrome is a contributory factor in prolonged unconjugated hyperbilirubinemia of the newborn. J Pediatr 134:441-446

10. Akaba K, Kimura T, Sasaki A, Tanabe S, Ikegami T, Hashimoto M, Umeda H, Yoshida H, Umetsu K, Chiba H, Yuasa I, Hayasaka K 1998 Neonatal hyperbilirubinemia and mutation of the bilirubin uridine-diphosphate-glucuronosyltransferase gene: a common missense mutation among Japanese, Koreans and Chinese. Biochem Mol Biol Int 46:21-26

11. Maruo Y, Nishizawa K, Sato H, Doida Y, Shimada M 1999 Association of neonatal hyperbilirubinemia with bilirubin UDP-glucuronosyltransferase polymorphism. Pediatrics 103:1224-1227

12. Huang CS, Chang PF, Huang MJ, Chen ES, Hung KL 2002 Relationship between bilirubin UDP-glucuronosyl transferase 1A1 gene and neonatal hyperbilirubinemia. Pediatr Res 52:601-605

13. Kaplan M, Renbaum P, Levy-Lahad E, Hammerman C, Lahad A, Beutler E 1997 Gilbert's syndrome and glucose-6-phosphate dehydrogenase deficiency: a dosedependent genetic interaction crucial to neonatal hyperbilirubinemia. Proc Natl Acad Sci USA 94:12128-12132

14. Galanello R, Cipollina MD, Carboni G, Perseu L, Barella S, Corrias A, Cao A 1999 Hyperbilirubinemia, glucose-6-phosphate dehydrogenase deficiency and Gilbert's syndrome. Eur J Pediatr 158:914-916

15. Iolascon A, Faienza MF, Perrotta S, Meloni GF, Ruggiu G, del Giudice EM 1999 Gilbert's syndrome and jaundice in glucose-6-phosphate dehydrogenase deficient neonates. Haematologica 84:99-102

16. Huang CS, Chang PF, Huang MJ, Chen ES, Chen WC 2002 Glucose-6-phosphate dehydrogenase deficiency, the UDP-glucuronosyl transferase 1A1 gene, and neonatal hyperbilirubinemia. Gastroenterology 123:127-133

17. Tirona RG, Leake BF, Merino G, Kim RB 2001 Polymorphisms in OATP-C: identification of multiple allele variants associated with altered transport activity among European- and African-Americans. J Biol Chem 276:35669-35675

18. Nozawa T, Nakajima M, Tami I, Noda K, Nezu J, Sai Y, Tsuji A, Yokoi T 2002 Genetic polymorphisms of human organic anion transporter OATP-C (SLC21A6) and OATP-B (SLC21A9): allele frequencies in the Japanese population and functional analysis. J Pharmacol Exp Ther 302:804-813

19. Tang TK, Huang CS, Huang MJ, Tam KB, Yen CH, Tang CJ 1992 Diverse point mutations result in glucose-6-phosphate dehydrogenase (G6PD) polymorphism in Taiwan. Blood 79:2135-2140

20. Lo YS, Lu CC, Chiou SS, Chen BH, Chang TT, Chang JG 1993 Molecular characterization of glucose-6- phosphate dehydrogenase deficiency in Chinese infants with or without severe neonatal hyperbilirubinemia. Br J Hematol 86:858-862

21. Chen HL, Huang MJ, Huang CS, Tang TK 1997 Two novel glucose-6-phosphate dehydrogenase deficiency mutations and association of such mutations with $\mathrm{F} 8 \mathrm{C} /$ G6PD haplotype in Chinese. J Formos Med Assoc 96:948-954

22. Huang CS, Luo GA, Huang MJ, Yu SC, Yang SS 2000 Variations of the bilirubin uridine-diphosphoglucuronosyl transferase 1A1 gene in healthy Taiwanese. Pharmacogenetics 10:539-544

23. Zaghloul H, Schulze KF 2001 Neonatal jaundice. In: Elzouki AY, Harfi HA, Nazer HM (eds) Textbook of Clinical Pediatrics. Lippincott Williams \& Wilkins, Philadelphia, pp 207-214

24. Balram C, Sabapathy K, Fei G, Khoo KS, Lee EJ 2002 Genetic polymorphisms of UDP-glucuronosyltransferase in Asians: UGT1A1 $* 28$ is a common allele in Indians. Pharmacogenetics 12:81-83

25. Sato H, Adachi Y, Koiwai O 1996 The genetic basis of Gilbert's syndrome. Lancet 347:557-558

26. Ando Y, Chida M, Nakayama K, Saka H, Kamataki T 1998 The UGT1A1 *28 allele is relatively rare in a Japanese population. Pharmacogenetics 8:357-360

27. Bosma PJ, Chowdhury JR, Bakker CT, Gantla S, de Boer A, Oostra BA, Lindhout D, Tytgat GN, Jansen PL, Oude-Elferink RP, Chowdhury NR 1995 The genetic basis of the reduced expression of bilirubin UDP-glucuronosyltransferase 1 in Gilbert's syndrome. N Engl J Med 333:1171-1175

28. Monaghan G, Ryan M, Seddon R, Hume R, Burchell B 1996 Genetic variation in bilirubin UDP-glucuronosyltransferase gene promoter and Gilbert's syndrome. Lancet 347:578-581 
29. Monaghan G, Foster B, Jurima-Romet M, Hume R, Burchell B 1997 UGT1 *1 genotyping in a Canadian Inuit population. Pharmacogenetics 7:153-156

30. Beutler E, Gelbart T, Demina A 1998 Racial variability in the UDP-glucuronosyl transferase 1 (UGT1A1) promoter: a balanced polymorphism for regulation of bilirubin metabolism? Proc Natl Acad Sci USA 95:8170-8174

31. Saeki M, Saito Y, Jinno H, Tohkin M, Kurose K, Kaniwa N, Komamura K, Ueno K, Kamakura S, Kitakaze M, Ozawa S, Sawada J 2003 Comprehensive UGT1A1 genotyping in a Japanese population by pyrosequencing. Clin Chem 49:1182 1185

32. Maruo Y, Nishizawa K, Sato H, Sawa H, Shimada M 2000 Prolonged unconjugated hyperbilirubinemia associated with breast milk and mutations of the bilirubin uridine diphosphate-glucuronosyltransferase gene. Pediatrics 106:E59
33. Kaplan M, Hammerman C, Renbaum P, Klein G, Levy-Lahad E 2000 Gilbert's syndrome and hyperbilirubinemia in ABO incompatible neonates. Lancet 356:652-653

34. Yamamoto K, Sato H, Fujiyama Y, Doida Y, Bamba T 1998 Contribution of two missense mutations (G71R and Y486D) of the bilirubin UDP glycosyltransferase (UGT1A1) gene to phenotypes of Gilbert's syndrome and Crigler-Najjar syndrome type II. Biochim Biophys Acta 1406:267-273

35. Tamai I, Nezu J, Uchino H, Sai Y, Oku A, Shimane M, Tsuji A 2000 Molecular identification and characterization of novel members of the human organic anion transporter (OATP) family. Biochem Biophys Res Commun 273:251-260

36. Wang P, Kim RB, Chowdhury JR, Wolkoff AW 2003 The human organic anion transport protein SLC21A6 is not sufficient for bilirubin transport. J Biol Chem 278:20695-20699 